\title{
Progressive drain withdrawal without suture removal: a technical note
}

\author{
Zaher Jandali ${ }^{1}$, Charles Yuen Yung Loh ${ }^{2}$, Athanassopoulos Thanassi ${ }^{2}$ \\ ${ }^{1}$ Department of Plastic, Aesthetic and Reconstructive surgery, Asklepios Klinik Wandsbek, Hamburg, Germany. \\ ${ }^{2}$ Ninewells Hospital Dundee, Scotland, UK.
}

Address for correspondence: Dr. Charles Yuen Yung Loh, Ninewells Hospital, Dundee, Scotland, UK. E-mail: Chloh_yy@hotmail.com

Sir,

Drains are traditionally used in a variety of surgical procedures; ${ }^{[1,2]}$ although there is limited evidence of their usefulness. ${ }^{[3]}$ Drains are classified based on various characteristics: as open or closed systems, as active versus passive, as prophylactic versus therapeutic; or by composition (e.g. polyurethane, silicone, or rubber). ${ }^{[2,4]}$ Closed vacuum drains apply negative suction $(60-80 \mathrm{kPa})$ in a sealed environment. ${ }^{[5]}$ Drains are often secured using a single suture or adhesive tape to prevent inadvertent removal. Complications from drains include pain, hemorrhage, drain entrapment, and retrograde bacterial migration that can result in postoperative infections..$^{[1,2]}$

We routinely use drains after flap reconstructions. For example, we place two or three vacuum suction drains in the gluteal myocutaneous rotation flaps that are used to cover sacral pressure sores. The drains are sutured for security and are completely removed if drainage is less than $30 \mathrm{~mL} /$ day. $^{[1,2]}$ If fluid production from the wound exceeds $30 \mathrm{~mL} /$ day for 5 days and is serous in nature, we progressively remove the drain in $3 \mathrm{~cm}$ steps until removal is complete.

The present report describes a method of progressive removal of an external drain without suture release. Specifically, we suture a loop through the skin and fix the drain by a double-loop through the first loop. One or two additional loops can be added if necessary. The suture is

\begin{tabular}{|l|l|}
\hline \multicolumn{2}{|c|}{ Access this article online } \\
\hline Quick Response Code: & Website: \\
\hline & www.parjournal.net \\
\cline { 2 - 3 } & \\
\hline
\end{tabular}

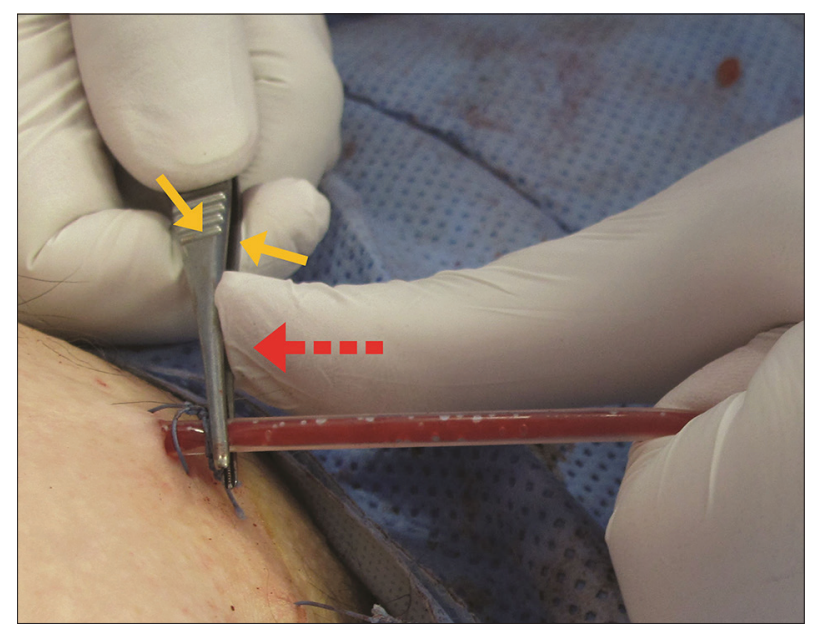

Figure 1: Progressive drain removal without suture release. Gentle traction on the drain with the forceps in place permits withdrawal of drain

tied with multiple knots, and a simple dressing over the drain is used for wound closure.

For drain withdrawal, the drain suture is soaked with disinfectant spray (Bode Cutasept ${ }^{\circledR} F$, Hamburg, Germany), to facilitate passage of the drain. The vacuum is then released to prevent the drain from adhering to the tissue. The forceps are positioned directly proximal to the securing suture and closed firmly. The drain is compressed and slid through the suture with gentle traction. If toothed forceps are used, the drain must be positioned proximal to the teeth to avoid tearing. This technique is applicable to drains of various diameters and materials.

We have used this technique to gradually extract drains during 7 years of high-volume plastic surgery [Figure 1]. Our patients have reported no discomfort or pain. The technique is safe and useful in situations where gradual drain withdrawal is advantageous, such as high-output seromas, postflap harvests, and groin dissections. It 
avoids the need for re-suturing and permits healing from the wound base. This method requires a certain level of training and caution when performing the retrieval. The drain's security must be checked after each withdrawal as it can loosen, resulting in premature drain removal.

\section{REFERENCES}

I. Dower R, Turner ML. Pilot study of timing of biofilm formation on closed suction wound drains. Plast Reconstr Surg 20 | 2; |30: | | 4 |-6.

2. Durai R, Mownah A, Ng PC. Use of drains in surgery: a review.J Perioper Pract 2009;19:180-6.
3. Kosins AM, Scholz T, Cetinkaya M, Evans GR. Evidence-based value of subcutaneous surgical wound drainage: the largest systematic review and meta-analysis. Plast Reconstr Surg 2013; I 32:443-50.

4. Durai R, Ng PC. Surgical vacuum drains: types, uses, and complications. AORN J 20I0;9I:266-7|.

5. Maier D, BeckA, Kinzl L, Bischoff M.The physics of vacuum therapy. Zentralbl Chir 2005; 130:463-8.

How to cite this article: Jandali Z, Yung Loh CY, Thanassi A. Progressive drain withdrawal without suture removal: a technical note. Plast Aesthet Res 2014;1:41-2.

Source of Support: Nil, Conflict of Interest: None declared.

Received: 05-04-2014; Accepted: 04-06-2014 